\title{
USABILITY OF EGOVERNANCE APPLICATION FOR CITIZENS OF PAKISTAN
}

\author{
Abdul Samad Dahri \\ Business Administration and Social Sciences \\ Mohammad Ali Jinnah University, Karachi, (Pakistan). \\ E-mail: dahriabdulsamad@gmail.com ORCID: https://orcid.org/0000-0003-4517-3493 \\ Shafiq-ur-Rehman Massan \\ QEC and Co-ordination \\ Mohammad Ali Jinnah University, Karachi, (Pakistan). \\ E-mail: srmassan@hotmail.com ORCID: https://orcid.org/0000-0001-6548-6513 \\ Ayaz Ali Maitlo \\ Department of Business Administration, \\ University of Sindh, Larkana Campus, (Pakistan). \\ E-mail: ayazalimaitlo@gmail.com ORCID: https://orcid.org/0000-0001-9831-8380
}

Recepción: 13/03/2020 Aceptación: 20/04/2020 Publicación: 30/04/2020

Gitación sugerida Suggested citation

Dahri, A. S., Massan, S., y Maitlo, A. A. (2020). Usability of eGovernance application for citizens of Pakistan. 3C Tecnología. Glosas de innovación aplicadas a la pyme. Edición Especial, Abril 2020, 265-277. http://doi.org/10.17993/3ctecno.2020.specialissue5.265-277 


\section{ABSTRACT}

eGovernance is a vital component of any nations' modern governmental structure and suitable for mass-scale adaptation. Pakistan has also established an eGovernance council for mitigation of the problems of the common man. One big step in this direction is the establishment of Pakistan Citizens' Portal (PCP) that facilitates eGovernance. Through the PCP app, citizens can directly lodge complaints and report their issues for immediate resolution.

This study looks at the important aspect of mobile usability through field tests to determine the viability of the PCP app in Pakistan. This study is vital towards determining the main factors for large scale adaptation of the PCP app and underlines the weaknesses of the present system.

Hence, the PCP app was evaluated in terms of efficiency and effectiveness according to ISO 92421-11. And the user satisfaction was measured through system usability satisfaction (SUS) on five-point Likert scale. The evaluation method included more than a dozen citizens of Sindh and findings showed that overall application enriched the user experience. However, the few areas of PCP were identified as needing improvements. The main areas that the PCP application needs to improve are the areas of registration and 'findability' which would further improve user satisfaction and experience.

\section{KEYWORDS}

EGovernance, Usability evaluation, Commoner satisfaction, Pakistan Citizen Portal, ISO designed usability standards. 


\section{INTRODUCTION}

eGovernance is the most recent trend of governance worldwide. Proper implementation of eGovernance requires SMART (Simple, Moral, Accountable, Responsive and Transparent) work ethic (Mehra \& Prabhu, 2013). The advent of information communication technology (ICT) has infused a new sphere of governmental intervention. The issues of the citizens are now being handled by eGovernance.

UNESCO defines eGovernance as the application of ICT towards participatory decision making hence improving information and service delivery (Obi, 2007). Similarly, with the advent of time the quality and type of services required by the common man in Pakistan is changing. Presently, the government is facing a challenge to manage the vast requirements of health, education travel, credit, security and documentation (Javaid \& Arfeen, 2017).

eGovernance process is a fairly recent trend globally. It helps improve interaction within the civil society by improving the processes of the government, interconnecting the citizens, and building viable interactions within society (Brown, et al. 2013). Though, literature reveals misconception regarding the difference between traditional and eGovernance, where, eGovernance appears to simply add more electronic devices to governance rather than cumbersome paper based work. Therefore, to change perception and practices, government needs to integrate technology with feasible policy change in the system (Arfeen, Khan, \& Amanullah, 2012).

According to united nations eGovernance survey, Pakistan was placed at 137 in 2003 out of 139 countries which declined to 146 in the year 2010 and further to 156 in 2012. There could be many factors to this decline, but the problem of Pakistan is not the lack of resources but bad governance (Rais, 2019). Even though, from layman of Asia to future tiger of Asia, needs bold steps by the government of Pakistan (Ministry of Planning, Development \& Reform Government of Pakistan, 2020). Yet, lethargic bureaucracy and lack of accountability left government helpless and leads inefficiencies in the system towards implementation of solutions to citizen problems and complaints.

Effective eGovernance implementation utilizes internet to provide of value added public services to civil society as per OECD (Ubaldi, 2009). eGovernance therefore needs 
connectivity of digital devices to deliver solutions and improve citizen lives (United Nations Conference on Trade and Development, 2009). Mobile devices have become more user friendly and useful and allow the users greater flexibility to perform more tasks. Another advantage is that mobile network signals cover $85 \%$ of the international population and $80 \%$ of these are smartphones users (Chaffey, 2016). Similarly, in Pakistan 2G mobile covers nearly $90 \%$ of population (PTA annual report 2014-2015). While, 57\% of rural and urban population have smartphones (Rizvi, 2018). This highlights penetration of mobile technology and indicates untapped eGovernance intervention potential in Pakistan. Therefore, eGovernance through mobile application holds the future for efficient and quality solutions of mitigation of citizen complaints.

Capitalizing over mobile access, current government tapped true potential and launched eGovernance Pakistan Citizens' Portal (PCP) mobile application 2018. This initiative is first of its kind in the history of Pakistan. This app providing access of 70,000 government offices to citizens at a single click and was recognized as 2nd best app in Global Summit held in Dubai February 2019. Moreover, 1.173 million users including overseas, and local citizens got registered. 553,125 complaints were lodged, and 509,153 complaints were resolved making rate of $92 \%$ including the provinces of Khyber Pakhtunkhwa, Sindh, Islamabad, Baluchistan and Azad Kashmir. While, Sindh provincial government was worst at $40 \%$ in terms of complaint resolution and even worse at $84 \%$ for complaints pending rate (News Desk, 2019).

On contrary, according to Furlow (2012), 95\% of mobile applications are not field tested. Since PCP mobile application is a new phenomenon in Pakistan, its independent field testing is essential for upgrades by product developers. Similarly, the past literature on mobile application usability comprises of surveys or literature reviews rather field evaluation (Dahri, Al-Athwari, \& Hussain, 2019). This study serves the purpose of field evaluation of PCP mobile application usability evaluation tests. Indeed, mobile usability evaluation test reveals the quality of how users adapt and utilize it and assess its actual field performance.

According to Coursaris and Kim (2011), mobile usability evaluation test is vital for smartphone users enabling the design of user friendly applications and determines success of the product (Baharuddin, Singh, \& Razali, 2013). In simple words, mobile usability 
evaluation test facilitates users of the technology to achieve their specific tasks with ease (Coursaris \& Kim, 2011).

\section{USER ASSESSMENT}

The participants were requested to perform a few simple tasks enlisted below:

1) Registering themselves with the system (Figure 1),

2) Application home screen usability (Figure 2)

3) Searching for relevant department (Figure 3)

4) Lodging a complaint (Figure 4),

5) Feedback (Figure 5),

6) ISO 9241-11 Usability framework (Figure 6)
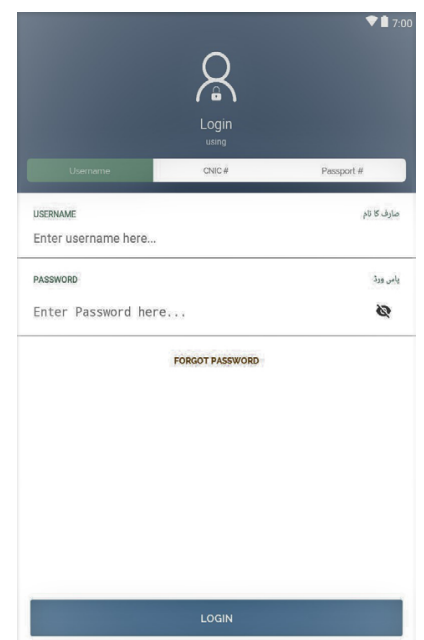

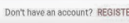

Figure 1. Registering themselves with the system.

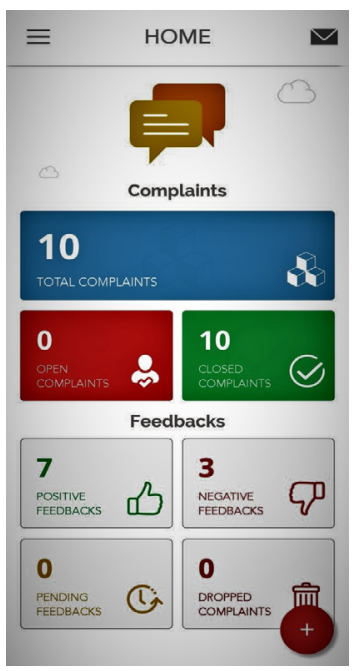

Figure 2. Application home screen usability.

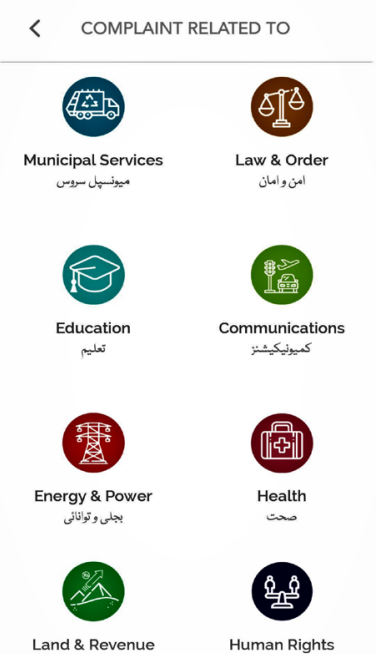

Figure 3. Searching for relevant department. 


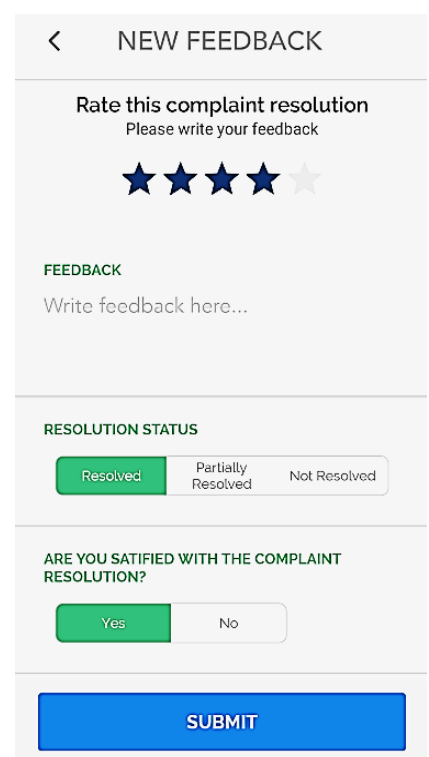

Figure 5. Feedback

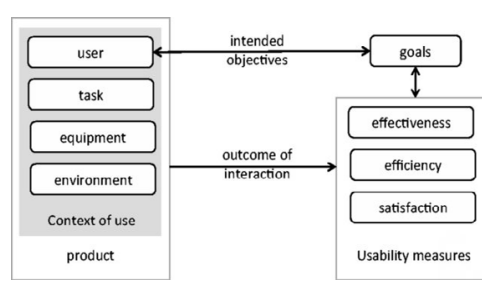

Figure 6. ISO 9241-11 Usability framework.

\section{MEASURES AND METHODS}

Quantitative usability design is provided by ISO-9241-11 (see Figure 6) that outlines user metrics with step by step implementation (UCD). The most common usability test is the typical task performance to measure effectiveness of the application, i.e. to what extent the user is able to achieve his desired goals. While efficiency is the level of resources and the amount of effort required by the user to attain accuracy and completeness of his desired goal. And last but not the least satisfaction or discontent is measurable by experiencing his acceptable usability level during the performance of a task.

Effectiveness as well as efficiency during interaction with the application may be measured by evaluating the completion of the given tasks and by counting the number of errors in user's attempt. Efficiency is to be measured by the resources and the efforts undertaken to achieve the desired task. Likewise, for general assessment of PCP, satisfaction is measured with system usability scale (SUS) which was developed and designed by Brooke in 1996 consist of 10 items on a Likert scale of 0-4 during the experience of the user interaction with the mobile application. We have utilized SUS in this study for validity, reliability and sensitivity scores that range from a mere 0 to about 100. The SUS score of 50 or below is 
considered to be poor, above 70 to be in the good range and while 85 or greater score is considered to be excellent (Bangor, Kortum, \& Miller, 2009).

The statistical methods used in this paper may be referenced from Shaikh, Massan and Wagan (2015), Memon and Shaikh (2016), Shaikh, Memon and Hussain (2016), Arain, Shaikh and Shaikh (2017), Khowaja et al. (2019), Shaikh, Massan and Wagan (2019), Soomro et al. (2019) and Sultan, Shaikh and Chowdhry (2020).

\section{RESULTS}

The number of participants were 15 from Hyderabad city of Sindh province as complaint resolution was the lowest from Sindh province of Pakistan. Most (70\%) of the participants were middle aged adults (30-40), 30\% of the participants ranged between 20-29 years of age, $70 \%$ of them had attained some education at college level and all used smartphones.

\subsection{EFFECTIVENESS}

Task 1 and 3 were recorded difficult having a total of $35 \%$ and $46 \%$ failure rates respectively. Task 4 and 5 were completed in the absence of any errors. Task 2 accumulated largest errors by participants and took more time. The kinds of error were:

1) Difficulty to remember steps of the procedure.

2) Department options and typically.

3) Complaint resolution information was repeated.

\subsection{EFFICIENCY}

Table 1 reveals that task 1 (Getting registered with the system), 2 (Application home screen usability), and 3 (Searching for relevant department) consumed more time due to expected difficulty and errors as well as had higher mean time. On the other hand, task 4 (Lodging a complaint) and 5 (Feed Back) consumed less mean time as that of task 1, 2, and 3.

Table 1. Time taken for each task per task.

\begin{tabular}{|c|c|c|c|c|c|}
\hline S.No & Task 1 & Task 2 & Task 3 & Task 4 & Task 5 \\
\hline Mean & 4.21 & 3.95 & 4.01 & 2.58 & 1.89 \\
\hline$(\mathrm{SD})$ & $(0.97)$ & $(0.55)$ & $(0.69)$ & $(1.09)$ & $(1.91)$ \\
\hline
\end{tabular}




\subsection{SATISFACTION}

The average SUS scores for the group was recorded at 85. This score indicates a sound satisfaction level across these PCP users. However, is a quite wide variation in scores of satisfaction that ranged from 62 to as high as 92 (at 30- point range). It was observed that 60 to 74 is a good rating and higher was excellent and under acceptable region where most of the participants' satisfaction scores were noticed.

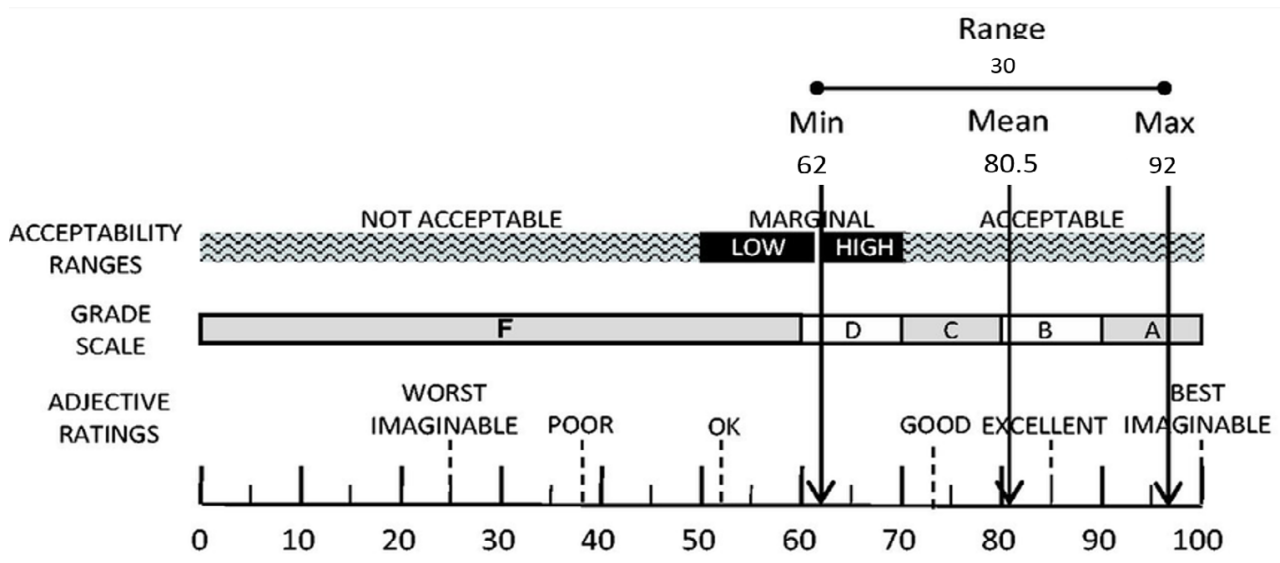

Figure 7. Variation in scores of satisfaction.

The tasks were based on the given guidelines of ISO for real time citizen interaction with application and validation. An error was reported whenever any user failed to complete any given task. The efficiency was estimated by measuring the average time utilized by a user towards the completion of each task from beginning to the successful completion. The evaluation of satisfaction score was done by measuring the SUS and the scores calculated by the use of guidelines of Brooke. The descriptive statistical data was obtained by the use of SPSS version 25.

\section{INTERPRETATION}

The interpretation of Task Performance, results, satisfaction and demographic trends show that task 1 (getting registered) and 3 (searching for relevant department) had most errors, was considered difficult and time consuming. These issues might arise due to lack of application comprehensiveness as, even task 1 (getting registered) took time of users though over several portals getting registered is routine task. However, overall user satisfaction was 
excellent. The results also indicate areas of improvement. Such as, multiple registration options, over informed grid on home screen and repetition of information regarding complaint resolution.

The demography of participants revealed that male participants were slightly more informed and performed better than female participants on SUS scores. Similarly, younger participants took less time and made few errors in task 1 and 3.

\section{RECOMMENDATIONS}

The study results tender some recommendations that might advance the experience and enhance the user satisfaction as follows:

1) User menu must be in list format.

2) Icon must illustrate departments included.

3) Registration process should follow less steps.

4) Application home screen should be user friendly.

5) Illiterate portion of citizens should also be considered.

6) Colors should be vivid and should match with actual logo of each department.

\section{CONTRIBUTIONS TO LITERATURE}

This is one of the foremost usability studies on the PCP application in the province of Sindh in Pakistan. It has addressed the issues of effectiveness, efficiency, and satisfaction by using validated scores are recommended by (Lyles, Sarkar, \& Osborn, 2014). This study utilizes and validates ISO designed usability standards of the SUS instrument towards the comparison of usability metrics and performance. This study bridges the present gap within the literatures of usability and helps identifying eGovernance improvement criteria of government of Pakistan. Following (Coursaris \& Kim, 2011) this study also contributes to understanding of demography and technology interaction in Pakistan's society and its influence on usability performance. The scores may be utilized to design future interventions 
for capturing the target population quickly and effectively. Hence, this study highlights main issued in the PCP application that must be removed to make it a successful and viable tool.

\section{CONCLUSION}

The study findings show that most of the users had good perceived usability satisfaction and only one-third of the users were rated as possessing little or poor usability. The results can be utilized by the developers objectively to design the necessary corrections in the PCP application. The objectivity of the results indicates the mismatch between the developer perception and the user experience which must be bridged.

\section{ACKNOWLEDGEMENT}

The authors wish to thank Dr. Hafiz Abdul Ghani Shaikh for his undaunted support.

\section{REFERENCES}

Arain, S., Shaikh, F., \& Shaikh, M. M. (2017). Problem of Traffic Congestion and Correlation Analysis of Driving behaviors in Qasimabad, Hyderabad. Mehran University Research Fournal of Engineering and Technology, 36(1), 139-148. https://trid.trb. $\mathrm{org} /$ view/ 1442479

Arfeen, M. I., Khan, N., \& Amanullah, M. (2012). Public Sector Innovation through e-Governance in Pakistan. Life Science, 9(3), 1226-1233. http://www.lifesciencesite. com/lsj/life0903/174_9492life0903_1226_1233.pdf

Baharuddin, R., Singh, D., \& Razali, R. (2013). Usability dimensions for mobile applications-a review. Research fournal of Applied Sciences, Engineering and Technology, 5(6), 2225-2231. https://doi.org/10.19026/rjaset.5.4776

Bangor, A., Kortum, P., \& Miller,J. (2009). Determining what individual SUS scores mean: Addinganadjectiveratingscale. Fournalof UsabilityStudies, 4(3), 114-123.http:/ / citeseerx. ist.psu.edu/viewdoc/download?doi=10.1.1.177.1240\&rep=rep 1\&type=pdf 
Brown, W., Yen, P.-Y., Rojas, M., \& Schnall, R. (2013). Assessment of the Health IT Usability Evaluation Model (Health-ITUEM) for evaluating mobile health (mHealth) technology. Fournal of Biomedical Informatics, 46(6), 1080-1087. https://doi. org/10.1016/J.JBI.2013.08.001

Ghaffey, D. (2016). Mobile marketing statistics compilation. https://doi. org / 10.15358/9783800653140-121

Coursaris, G. K., \& Kim, D. J. (2011). A meta-analytical review of empirical mobile usability studies. Fournal of Usability Studies, 6(3), 117-171. http://uxpajournal.org/ wp-content/uploads/sites/8/pdf/JUS_Coursaris_May_2011.pdf

Dahri, A. S., Al-Athwari, A., \& Hussain, A. (2019). Usability Evaluation of Mobile Health Application from AI Perspective in Rural Areas of Pakistan. International Fournal of Interactive Mobile Technologies, 13(11), 213-225. https://doi.org/10.3991/ ijim.v13i11.11513

Furlow, B. (2012, November 2). mHealth apps may make chronic disease management easier. Clinical Advisor. https://www.clinicaladvisor.com/home/features/mhealth-appsmay-make-chronic-disease-management-easier/

Javaid, M., \& Arfeen, M. (2017). Impact of eGovernment on Citizen Satisfaction: A Case of Federal Government Agencies in Pakistan, 221-237. https://doi.org/10.1007/978-3-31965930-5_19

Khowaja, A., Mahar, M. H., Lashari, H. N., Wasi, S., \& Massan, S.-R. (2019). Personality Evaluation of Student Community using Sentiment Analysis. Nternational Fournal of Computer Science E Network Security (IFCSNS), 19(3), 167-180. https://www. researchgate.net/publication/332395067_Personality_Evaluation_of_Student_ Community_using_Sentiment_Analysis

Lyles, G. R., Sarkar, U., \& Osborn, G. Y. (2014). Getting a technology-based diabetes intervention ready for prime time: a review of usability testing studies. Current Diabetes Reports, 14(10), 534. https://doi.org/10.1007/s1 1892-014-0534-9 
Mehra, K., \& Prabhu, G. S. R. (2013). E-Governance: Concepts and Case Studies : ix. PHI Learning Private Limited.

Memon, A. J., \& Shaikh, M. M. (2016). Confidence bounds for energy conservation in electric motors: An economical solution using statistical techniques. Energy, 109, 592-601. https://doi.org/10.1016/J.ENERGY.2016.05.014

Ministry of Planning, Development \& Reform Government of Pakistan. (2020). Pakistan 2025. One Nation - One Vision. https://www.pc.gov.pk/uploads/vision2025/ Pakistan-Vision-2025.pdf

News Desk. (2019, October 3). PTI govt takes lead in citizens' complaint resolution. The Express Tribune. https://tribune.com.pk/story/2071030/1-pti-govt-takes-lead-citizenscomplaint-resolution/

Obi, T. (2007). E-governance: A Global Perspective on a New Paradigm (p. 27). IOS Press.

Rais, R. B. (2019). Citizens Portal: Improving governance through technology. Retrieved November 21, 2019, from http://arabnews.pk/node/1587581

Rizvi, J. (2018, November 9). Pakistan's urban-rural mobile ownership divide set to close soon, study shows. The News. https://www.thenews.com.pk/print/391338-pakistan-s-urbanrural-mobile-ownership-divide-set-to-close-soon-study-shows

Shaikh, M. M., Massan, S.-R., \& Wagan, A. I. (2015). A new explicit approximation to Colebrook's friction factor in rough pipes under highly turbulent cases. International Fournal of Heat and Mass Transfer, 88, 538-543. https://doi.org/10.1016/j. ijheatmasstransfer.2015.05.006

Shaikh, M. M., Massan, S.-R., \& Wagan, A. I. (2019). A sixteen decimal places' accurate Darcy friction factor database using non-linear Colebrook's equation with a million nodes: A way forward to the soft computing techniques. Data in Brief, 27, 104733. https://doi.org/10.1016/J.DIB.2019.104733 
Shaikh, M. M., Memon, A. J., \& Hussain, M. (2016). Data on electrical energy conservation using high efficiency motors for the confidence bounds using statistical techniques. Data in Brief, 8, 529-535. https://doi.org/10.1016/J.DIB.2016.06.004

Soomro, M. A., Memon, S. A., Shaikh, M. M., \& Channa, A. (2019). Indoor air $\mathrm{CO} 2$ assessment of classrooms of educational institutes of hyderabad city and its comparison with other countries. In AIP Conference Proceedings, 2119(1), 020014. AIP Publishing LLC. https://doi.org/10.1063/1.5115373

Sultan, M., Shaikh, M. M., \& Chowdhry, N. P. (2020). Comparative Analysis of Knee Joint Replacement and Stem Cells Therapy Treatment for Knee Osteoarthritis Using Statistical Techniques. Research in Medical and Engineering Sciences, 8(4), 887-897. https://crimsonpublishers.com/rmes/pdf/RMES.000693.pdf

Ubaldi, B. (2009). OECD e-Government Studies: Rethinking e-Government Services; User-Centred Approaches. www.oecd.org/gov/egov/services

United Nations Conference on Trade and Development. (2009). Information Economy Report 2009, Trends and Outlook in Turbulent Times. United Nations. https: / / unctad.org/ en/Docs/ier2009_en.pdf 